P-ISSN: 2541-6960; E-ISSN: 2549-8754

Yupa: Historical Studies Journal

Vol. 5 No. 1, 2021 (8-14)

http://jurnal.fkip.unmul.ac.id/index.php/yupa

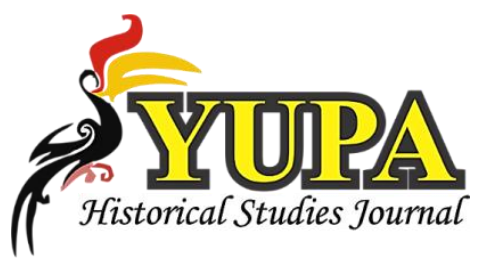

\title{
Sejarah dan Dampak Misi Kristen di Kampung Besiq, Kutai Barat Tahun 1966
}

\author{
Agnesia Pauline ${ }^{1}$, Demsy B. Salindeho ${ }^{2}$ Jamil $^{3}$ \\ ${ }^{1}$ Universitas Mulawarman, Samarinda, Indonesia \\ ${ }^{2}$ Universitas Mulawarman, Samarinda, Indonesia \\ ${ }^{3}$ Universitas Mulawarman, Samarinda, Indonesia
}

19agnesiapauline03@gmail.com, ${ }^{2}$ demsy.salindeho@fkip.unmul.ac.id, ${ }^{3}$ jamil@fkip.unmul.ac.id

\begin{tabular}{ccc}
\hline Received & Accepted & Published \\
$17 / 07 / 2021$ & $03 / 08 / 2021$ & $21 / 08 / 2021$ \\
\hline
\end{tabular}

\begin{abstract}
The existence of the Dutch ruling in Indonesia brought the development of Protestant Christianity. Continued with the entry of zending who came with the spirit of Pietism (pious people who practice God's word) which in principle prioritizes repentance, teaching faith experiences in daily life and in worship. They were sent to carry out the mission of preaching the gospel to all mankind who do not yet believe in the Lord Jesus Christ. In West Kutai, Christianity is also growing rapidly as evidenced by the existence of the majority of people who embrace Protestant Christianity. One of them is Besiq village, which is located in the interior of West Kutai, Christianity has also developed in this village where the majority of the people embrace Protestant Christianity.
\end{abstract}

Keywords: Christian Religious Mission, West Kutai, Besiq Village

Abstrak Keberadaan Belanda yang berkuasa di Indonesia membawa perkembangan bagi agama Kristen Protestan. Berlanjut dengan masuknya para zending yang datang dengan semangat Pietisme (orang saleh yang menjalankan firman Tuhan) yang pada prinsipnya mengutamakan pertobatan, mengajar pengalaman imani dalam hidup sehari-hari maupun didalam kebaktian. Mereka diutus untuk melakukan misi pemberitaan injil kepada seluruh umat manusia yang belum percaya kepada Tuhan Yesus Kristus. Di Kutai Barat agama Kristen juga berkembang pesat terbukti dengan adanya masyarakat yang mayoritas memeluk agama Kristen Protestan. Salah satunya kampung Besiq yang berada di pedalaman Kutai Barat agama Kristen juga telah berkembang di kampung ini dimana masyarakatnya mayoritas memeluk agama Kristen Protestan.

Kata kunci : Misi Agama Kristen, Kutai Barat, Kampung Besiq 


\section{PENDAHULUAN}

Negara Republik Indonesia mengakui enam Agama di Indonesia. Agama-agama tersebut ialah Hindu, Budha, Islam, Khatolik, Kristen, dan Kong Hu Chu. Tiap pemeluk agama dilindungi oleh pemerintah dan Undang-Undang Dasar 1945, sehingga setiap warga negara bebas melaksanakan ajaran agamanya masing-masing. Yang menjadi fokus utama dalam penulisan ini ialah bagaimana sejarah misi Kristen khususnya di kampung Besiq Kutai Barat provinsi kalimantan timur. Jadi dalam latar belakang penulis akan membahas secara singkat sejarah agama Kristen yang masuk dan berkembang di daerah-daerah Indonesia hingga di pedalaman Kalimantan.

Keberadaan agama Kristen Protestan di Indonesia berawal dari kedatangan VOC. Adapun awal mula gereja Protestan di mulai dengan prostenisasi orang Katolik di Ambon, Ternate, dan Minahasa sejak pertengahan abad ke 17. Keberadaan Belanda yang berkuasa di Indonesia membawa perkembangan bagi agama Kristen Protestan. Masyarakat yang telah memeluk agama Katolik sebelumnya didaerah itu diharuskan memeluk agama Kristen Protestan Alasan tindakan ini bersifat Praktis dan Politis (Abdullah, 2012 : 203).

Berbeda dengan kedatangan bangsa Portugis dan Spanyol yang selain mencari kekayaan, kejayaan, dan juga menyebarkan agama Katolik, Belanda datang dengan tujuan murni berdagang. VOC sebagai pedagang dan penguasa yang beragama Kristen Protestan mendapat utusan dari Gereformeerde kerken (kelompok gereja di Belanda) untuk menyebarkan agama tersebut. Namun kepentingan dagang tetap didahulukan. Seiring dengan perubahan pemerintah sejak runtuhnya VOC, agama Kristen Protestan mengalami stagnasi karena tidak kepedulian pemerintah (Adullah, $2012: 203$ )

Sewaktu pemerintahan Gubernur Jendral Daendels bertiuplah angin segar kebebasan beragama. Kebebasan beragama yang diteruskan oleh Gubernur Raffles berlanjut dengan masuknya para zending yang pertama. Para zending datang dengan semangat Pietisme (orang saleh yang menjalankan firman Tuhan) yang pada prinsipnya mengutamakan pertobatan (hidup individu orang Kristen yang baru), mengajar pengalaman imani dalam hidup sehari-hari maupun didalam kebaktian. Zending/Penginjil yang datang tidak dikirim oleh pemerintah atau kerajaan melainkan oleh lembaga-lembaga misi yang pada saat itu memiliki kesadaran akan kewajiban memberitakan Injil di seluruh dunia (Abdullah, 2012 : 205).

Agama Kristen Protestan juga berkembang di antara suku-suku asli di pedalaman Kalimantan yang pada umumnya masih memeluk agama atau kepercayaan suku. Di Kalimantan keKristenan berkembang di lingkungan suku Dayak hal ini merupakan faktor dari kebijakan politik etis yang medorong pendidikan, kesehatan, dan pertanian. Keberadaan Zending akan sangat berguna untuk membantu pelaksanaan program-program tersebut dengan membawa semangat memberitakan Injil dalam proses pelaksanaan program politik etis terutama di 
daerah-daerah terpencil. Hal ini disambut baik oleh masyarakat terutama kepala suku yang kemudian membawa kerabat sukunya untuk dibaptis (Adullah,2012 : 209).

Kutai Barat merupakan salah satu kabupaten yang terletak di Kalimantan Timur dimana penduduk aslinya adalah suku Dayak dan memiliki mayoritas penduduk memeluk agama Kristen Protestan, hal ini tentu tidak terlepas dari peran para Zending yang diutus untuk melakukan misi pekabaran injil didaerah ini. (Woga) 2002 : 13-14 dalam konteks Kekristenan misi dipahami dalam arti pengutusan gereja universal ke dalam dunia untuk melakukan pekabaran Injil dan menjangkau orang-orang yang belum percaya kepada Yesus Kristus sebagai Tuhan dan Juru Selamat yang membebaskan manusia dari segala dosa-dosanya melalui kelompok misionaris.

Misi pekabaran Injil juga telah berkembang di daerah atau perkampungan pedalaman Kutai Barat salah satunya di kampung Besiq yang berada tepat di Hulu Sungai Kedang Pahu. Misi yang datang di kampung Besiq merupakan utusan lembaga misi Chinese Foreign Missionary Union (CFMU). CFMU adalah lembaga misi yang didirikan oleh Pdt. Jaffray bersama beberapa rekan pendeta gereja Tionghoa di Tiongkok yang di utus melakukan misi ke daerah Asia Tenggara termasuk Indonesia sampai kepedalaman Kalimantan.

Misi ini dimulai pada Februari 1932 Pdt. Yason S. Lim dan Pdt. Liem Kwang (Misionaris CFMU) datang ke Samarinda dan melakukan misi di pedalaman Mahakam. Untuk memberitakan injil kepada orang-orang suku Dayak yang belum percaya Tuhan. Tempat pelayanan Pdt. Yason S. Lim dan Pdt. Liem Kwang berada di daerah Kabupaten Kutai Barat. Dimulai dari kampung muara Lawa (Lambing), Damai sekitarnya di daerah sungai Tuang, sungai Kedang Pahu, sungai Nyuatan (Dayak Benuaq), Empaku, Sakaq Tada sampai ke Gemuruh (Dayak Tunjung), dan hulu sungai Lawa (Bentian besar) : suku Bentian hingga perbatasan Kalimantan Tengah. Setelah Pdt. Yason S. Lim dan Pdt. Liem Kwang meninggalkan daerah pelayanannya kemudian digantikan oleh Pdt. Chang Shih Ying, Misi pekabaran Injil terus dilakukan hingga di Hulu Sungai Kedang Pahu tepatnya di kampung Besiq. Pelayanan misi Pdt. Chang Shih Ying dimulai pada tahun 1963 dan merupakan misi Kristen pertama yang masuk di kampung Besiq

\section{METODE}

Jenis penelitian yang digunakan adalah penelitian sejarah. Dengan metode ini penulis berusaha mendeskripsikan kembali peristiwa sejarah dimasa lampau sehingga dapat menghasilkan Historiografi sejarah yang dapat dipertanggung jawabkan secara ilmiah. Dalam penerapan metode sejarah ini menggunakan tahapan-tahapan kerja, sebagai mana dikemukakan oleh Daliman (2012 : 28), antara lain : 1. Heuristik, yakni pengumpulan sumbersumber data terkait penelitian. 2. Kritik, memastikan apakah sumber yang diperoleh sudah akurat dan sesuai topik yang akan diteliti. 3. Interpretasi, menafsirkan keterangan-keterangan 
dari sumber-sumber sejarah. 4. Historiografi, tahap penulisan yakni menyampaikan data yang diperoleh dalam bentuk tulisan.

Teknik pengumpulan data yang digunakan dalam penelitian ini adalah Observasi (pengamatan) secara langsung kelokasi penelitian, interview (wawancara) 4 responden utama yang mengetahui sejarah misi Kristen yang ada di kampung Besiq, dan dokumentasi berupa foto selama melakukan kegiatan penelitian sebagai bukti dilapangan..

\section{HASIL DAN PEMBAHASAN}

\section{Sejarah masuknya Agama Kristen di Kampung Besiq}

Sejarah misi Kristen atau awal masuknya Agama Kristen di kampung Besiq diketahui bahwasannya Pdt Chang Shih Ying merupakan tokoh pertama perintis atau yang membawa misi Kristen di kampung Besiq, beliau adalah tokoh yang diutus oleh lembaga misi Chinese Foreign Missionary Union (CFMU) yang berasal dari daratan China.

Hal ini juga dikemukakan dalam sebuah buku Dapertemen Teologia GKKA Indonesia (2003 : 48) menyebutkan bahwa Pdt. Chang Shih Ying merupakan utusan misionaris CFMU periode kedua bersama 15 misionaris lainnya yang diutus untuk memberitakan injil di Indonesia dan Vietnam. Pdt. Chang Shih Ying sendiri kebetulan diutus melakukan misi injil di Indonesia tepatnya dibagian pedalaman Kalimantan Timur yaitu di daerah Kutai Barat bagian pesisir Sungai Lawa, Sungai Kedang Pahu, dan Sungai Nyuatan. Dalam catatan perjalanan misi Pdt. Yulius di Kutai Barat, beliau menuliskan Misi CFMU di Kutai Barat dimulai pada Februari 1932 pada masa ini di pimpin oleh Pdt. Yason S. Lim dan Pdt. Liem Kwang (Misionaris CFMU periode pertama) yang datang ke Samarinda dan melakukan misi di pedalaman Mahakam. Untuk memberitakan injil kepada orang-orang suku Dayak yang belum percaya Tuhan. Tempat pelayanan Pdt. Yason S. Lim dan Pdt. Liem Kwang berada di daerah Kabupaten Kutai Barat. Dimulai dari kampung muara Lawa (Lambing), Damai sekitarnya di daerah sungai Tuang, sungai Kedang Pahu, sungai Nyuatan (Dayak Benuaq), Empaku, Sakaq Tada sampai ke Gemuruh (Dayak Tunjung), dan hulu sungai Lawa (Bentian besar): suku Bentian hingga perbatasan Kalimantan Tengah.

Setelah Pdt. Yason S. Lim dan Pdt. Liem Kwang meninggalkan daerah pelayanannya kemudian digantikan oleh Pdt. Chang Shih Ying, Misi pekabaran Injil dilanjutkan sampai di Hulu Sungai Kedang Pahu, beliau melakukan misi di pesisir sungai kedang pahu dengan menggunakan perahu ketinting sebagai transportasinya karena memang perahu dan sungai adalah akses satu-satunya pada saat itu dan merupakan penghubung dari suatu kampung ke kampung lainnya dapat dilihat juga gereja GKKAI yang merupakan hasil dari misi Pdt. Chang Shih Ying banyak berdiri di daerah perkampungan yang berada dipesisir sungai kedang pahu 
maupun sungai nyuatan seperti di kampung Damai, Bomboi, Muara Tokong, dan di Kampung Besiq salah satunya.

Hal serupa juga ditulis dalam Ronda $(2018: 67,68)$ menjelaskan bahwa ada beberapa penginjil yang yang diutus ke Indonesia. Terkhususnya didaerah Kalimantan Timur tepatnya di Samarinda diutus penginjil yaitu Pdt. Yason S. Linn dan Pdt. Liem Kwang Ling untuk melayani orang-orang yang ada di pedalaman Sungai Mahakam. Pelayanan mereka selanjutnya dilanjutkan oleh Pdt. Chang Shih Ying yang berhasil membuka ladang baru/tempat pelayanan di pedalaman Kalimantan Timur.

Pelayanan misi Pdt. Chang Shih Ying dimulai pada tahun 1966-1967 dan merupakan misi Kristen pertama yang masuk di kampung Besiq, misi pekabaran injil yang dilakukan oleh Pdt. Chang Shih Ying dengan menyampaikan injil kerumah-rumah masyarakat pertama-tama kepada Tua-tua adat (kepala Suku) yang dianggap paling berpengaruh di kalangan masyarakat pada saat itu. Langkah penyampaian injil pertama kepada kepala suku ini dilakukan untuk mempermudah penyampaian injil selanjutnya kepada masyarakat lainnya. Kepala suku atau masyarakat yang merespon Injil yang disampaikan dan bertobat langsung dibaptis menjadi Kristen.Tokoh adat (kepala suku) yang pertama menerima Injil yaitu Alm. Bapak Imansyah atau sering dipanggil dengan sebutan Kakah Mulai. Beliau adalah tokoh pertama yang menerima injil dan dibaptis pertama pada tahun 1968 lalu diangkat sebagai ketua majelis (pengurus gereja) pertama dikampung Besiq dan beliaulah salah satu tokoh masyarakat yang aktif dalam melakukan kegiatan keagamaan pada saat itu.

Perjalanan misi Pdt.Chang Shih Ying di kampung Besiq tidak selalu berjalan dengan lancar ia juga mengalami kesulitan karena masyarakat setempat masih menganut kepercayaan lama atau agama asli nenek moyang yang kita kenal dengan ajaran animisme dan dinamisme. Mereka masih melakukan ritual adat-istiadat mempercayai kepada ruh nenek moyang, dan benda-benda mati yang dianggap memiliki kekuatan atau keajaiban yang sifatnya luar biasa sehingga lahir pemujaan terhadap benda-benda mati tersebut. Hal ini dituangkan masyarakat dalam ritual adat seperti Upacara Belian (upacara penyembuhan) dan kuwangkai (upacara kematian) yang masih bisa dilihat hingga saat ini. Meskipun sudah jarang dilakukan oleh masyarakat karena sebagaian besar mereka sudah memiliki agama.

Walaupun mengalami tantangan dan masalah diatas namun Pdt. Chang Shih Ying dalam misinya tidak pernah mendapat penolakan secara ekstrim seperti kekerasan, pengusiran bahkan upaya pembunuhan hal itu tidak pernah terjadi di masyarakat, karena dalam proses misi yang dilakukan Pdt. Chang Shih Ying tidak pernah dengan cara memaksa ataupun kekerasan terhadap masyarakat beliau tetap menghargai setiap kebudayaan, kebiasaan dan kepercayaan yang dianut oleh masyarakat setempat. Hal ini yang membuat mereka menerima 
kehadiran beliau walaupun sebagian tidak langsung menerima Injil dan masih menganut kepercayaan mereka sendiri.

Tahun 1981 pelayanan misi Pdt. Chang Shih Ying berakhir dikampung besiq, beliau telah emeritus (Selesai masa tugas pelayanan) dan pindah ke Jakarta. Di kampung Besiq sempat lama mengalami kekosongan hamba Tuhan/pendeta tidak ada yang bertugas disana. Yang menggantikan atau melanjutkan misi injil sementara adalah ketua majelis (masyarakat biasa menjadi pengurus gereja). yang tadinya Ibadah dilakukan di Rumah-rumah warga karena belum memiliki gedung gereja untuk beribadah, Pada tahun 1985 di bangunlah gedung gereja secara permanen yang digunakan sebagai tempat ibadah umat Kristen dikampung Besiq sampai hari ini.

Setelah sekian lama barulah datang seorang hamba Tuhan yang diutus bertugas di Besiq Yaitu Pdt. Duit. Beliau sesekali berkunjung mengisi Pelayanan Injil di kampung Besiq, setelah Pdt. Duit maka diutus kembali seorang hamba Tuhan oleh sinode gereja GKKAI yang berpusat di surabaya beliau adalah Pdt. Eden, beliau melanjutkan pelayanan misi di kampung Besiq dan mengirim para pemuda-pemudi setempat untuk melanjutkan studi sebagai hamba Tuhan di Makassar. khawatir kedepan tidak ada hamba Tuhan lagi yang melanjutkan misinya. Setelah menyelesaikan studi sebagai hamba Tuhan, salah satu dari mereka kemudian ditempatkan sebagai Pendeta di kampung Besiq menggantikan Pdt. Eden. Beliau adalah Pdt. Tingkang setelah beliau digantikan oleh Pdt. Ruslan dan terjadi beberapa kali pergantian hamba Tuhan yang bertugas dikampung Besiq, sampai pada akhir tahun 2019 Pendeta yang melayani adalah Ev. Jemi Gideon S.Th.

\section{Dampak Misi Kristen terhadap Masyarakat di Kampung Besiq}

Berdasarkan wawancara kepada Bapak Ngeban pada 21 Maret 2019 : "ya adanya misi kristen Menumbuhkan sifat terbuka dan toleransi diantara masyarakat yang sudah beragama dengan masyarakat yang masih menganut kepercayaan nenek moyang, selain itu kehidupan sempekat ( rukun dalam masyarakat dan saling bahu-membahu ) sangat dijunjung tinggi masyarakat di kampung Besiq. Selain itu dampak sosial juga dapat dilihat dari peran kepala adat yang dahulu merupakan tokoh tertinggi atau pemimpin dalam masyarakat dan agama yang dianut namun sekarang pemimpin agama ialah seorang pendeta. Adapun kegiatan sosial yang dilakukan oleh gereja yaitu seperti pembinaan kepada anak usia dini, remaja-pemuda, orang tua, dan lansia"

Dampak sosial misi Kristen terhadap masyarakat dikampung Besiq yaitu tumbuhnya sifat keterbukaan dan toleransi diantara masyarakat terbukti ketika salah satu masyarakat yang memilih bertobat menjadi Kristen mereka tetap hidup rukun berdampingan dengan masyarakat yang masih menganut kepercayaan nenek moyang. Hidup rukun masyarakat dikampung Besiq masih terbentuk sampai sekarang setiap masyarakat selalu bahu membahu dan saling tolong- 
menolong. Hidup sempekat (rukun terhadap sesama) ini yang selalu dijunjung tinggi masyarakat dikampung Besiq sampai saat ini. Adapun dampak sosial pada perkembangan selanjutnya yaitu dibentuklah lembaga PPA untuk pembinaan terhadap anak-anak usia dini, program pembinaan terhadap remaja, pemuda, orang tua, pasutri, dan lansia. Program ini bertujuan untuk menumbuhkan pemahaman rohani dan cara hidup umat Kristen yang saling mengasihi dalam masyarakat.

Selain dampak sosial kehadiran misi Kristen juga membawa dampak yang cukup besar dalam kebudayaan masyarakat dikampung Besiq. Masuknya misi Kristen di kampung Besiq membawa dampak terhadap kebudayaan masyarakat setempat, kehadiran misi ini membuat masyarakat satu-persatu mulai melepaskan ajaran dan ritual adat-istadat nenek moyang. Diamana masyarakat yang dahulu melakukan ritual belian untuk upacara penyembuhan teradap seseorang yang sakit untuk meminta kepada liaw (arwah nenek moyang) untuk melepas penyakit yang diderita dan meminta kesembuhan. lambat laun mereka mulai meninggalkan ritual itu dan lebih memilih didoakan dan membawa seseorang yang sakit ke rumah sakit.

\section{KESIMPULAN}

Para zending datang dengan semangat Pietisme yang mengutamakan pertobatan, mengajar pengalaman imani dalam hidup sehari-hari maupun didalam kebaktian. Di Kutai Barat agama Kristen berkembang pesat dengan adanya masyarakat yang mayoritas memeluk agama Kristen Protestan. Kampung Besiq yang berada di pedalaman Kutai Barat mayoritas masyarakatnya memeluk agama Kristen yang berdampak pada perubahan sosial dan budaya.

\section{REFERENCES / REFERENSI}

Abdullah, T. Dkk. (2012). Indonesia Dalam Arus Sejarah (Kolonialisme dan perlawanan). PT. Ichtiar Baru Van Hoeve.

Daliman, A. (2015). Metode Penelitian Sejarah. Yogyakarta: Penerbit Ombak.

GKKA Indonesia, D. T. (2003). Dasar Iman Yang Teguh. Makassar : Departemen Teologia GKKA Indonesia.

GKKA-I, S. (2018). 89 Tahun Chinese Foriegn Missionary Union . Surabaya: Sinode GKKA-I.

Woga, E. (2002). Dasar-Dasar Misioligi. Yogyakarta: Kanisius. 